\title{
Art and Text as Living Inquiry into Anti-Immigration Discourse
}

\author{
Christian Faltis \\ University of California, Davis, USA
}

This paper examines the connections between art and text regarding the (mis) treatment of Mexican immigrants, particularly in schools. The paper discusses the harsh realities of anti-immigrant discourse through a series of oil paintings created to depict selected issues of Mexican immigrant experiences that are also written about in text. The main argument of this paper is that art expands the imagination of written text to provoke meanings that are interconnected to textual representation and, at the same time, creates openings for the unfolding of visceral sensations and critical meaning.

Mexican Immigrants in the Southwest and Beyond

The Distribution of Sadness

The Distribution Of Disdain

My Stance Toward Social Justice For Mexican Immigrants In The United States

Art and Political Scholarship

Visceral Realism in Art and Text around Mexican Immigrants

Notes

References

\section{Mexican Immigrants in the Southwest and Beyond}

Centuries before territories in the Southwest achieved statehood, Mexicans traveled back and forth dynamically from southern Mexico to northern routes in Arizona and California to trade goods and wares with indigenous groups in the Southwest, forming communities and histories across time and space (Vélez-Ibañez, 1996). In more recent history, a large number of Mexicans settled in the United States after the Mexican revolution in the early 1900s (Hondagneu-Sotelo, 1997; Rosales, 1999). During WWII and the ensuing years, tens of thousands of braceros, Mexican immigrants who worked the fields of Arizona and California, fed the nation. In the 1960s and 1970s, Mexican immigrants, paid below minimum wage, cleared the land and built the homes that expanded major cities and industries throughout the Southwest. Significant Mexican migration northward occurred again from the late 1980s to the early 2000s, partly due to the economic crisis faced in Mexico and to the pull of new job opportunities as the U.S. economy (housing and labor markets) grew during the 1990s and early 2000s. Along with Mexican immigrants came immigrants from Central America (e.g., Guatemala, El Salvador, and Honduras), and many 
of these immigrants lived within Mexican communities where they shared a common first language. The focus of this paper is on Mexican immigrants, but Central American immigrants have experienced many of the same kinds of dehumanizing treatments.

The constant migration of Mexicans to and from Mexico into the United States across time has led, on one hand, to a strengthening of family ties across both sides of the border and, on the other hand, to a growing animosity by conservative politicians and hoi polloi alike toward Mexican immigrants, particularly since 2007 when the housing bubble burst and the economy fell into a severe recession. As the migrant landscape grew across time and space, so too did the distribution of sadness and disdain experienced by Mexican immigrants in the United States.

\section{The Distribution of Sadness}

Vélez-Ibañez (1996) introduced the concept of "distribution of sadness" to suggest that the long standing demonization, coupled with the commodification of Mexican immigrants in Arizona territory since the 1880 s, has sadly contributed to an overrepresentation of the children of Mexican immigrants associated with health, economic, and behavioral problems. On the one hand, Mexican immigrants are positioned as an undesirable drain on society, using costly health services and public school resources and engaging in criminal activities, such as gang violence and drug trafficking. Their migration from Mexico to join with family members and look for work has been criminalized; Mexican immigrants are referred to as "illegal aliens." On the other hand, Mexicans immigrants are coveted for their hard work ethic and for cheap labor, as commodities that are bought and sold in the marketplace, not for the value they bring as families with a diversity of experience and a long history in what is now the Southwestern United States.

Sadly, there has never been a long-term investment by the United States to support Mexican immigrants and their children in school or society. Over the past hundred years, Mexicans have been courted and used as a cheap labor commodity (Vélez-Ibañez, 2004). When the economy experiences a downturn as in the early 1990s and late 2000s, Mexicans are portrayed as threatening "American jobs" and as a menace to society, in need of being rounded up and sent back to Mexico. Anti-immigrant rhetoric paints the children of Mexican immigrants as a burden to schools and health centers. However, although K-12 education has made some curricular adjustments for children of immigrants (e.g., ESOL, sheltered instruction, and transitional bilingual education), these are sporadic and most often target English learners in the elementary grades. Bilingual education in various formats has been employed only sparsely and sporadically from the late 1960 s as an educational remedy to overcome the perceived "language deficits" of poor English language learners. When money and effort have been invested in schools, it has been aimed primarily at teaching 
English to children of immigrants, but such investments have happened only after particular federal or state suits have challenged school districts (e.g., Lau v. Nichols, 1974; Castañeda v. Pickard, 1981; Horne v. Flores, 2009) that, by doing nothing, were found to be discriminating against children of immigrants who spoke a language other than English (Crawford, 1994).

Part of the distribution of sadness Velez-Ibañez (2004) bemoans is that despite the undeniable contributions and sacrifices peoples of Mexican origin have made in building the United States and keeping it safe, widespread and long-term support for the health and education of children of Mexican immigrants has been sorely lacking. These children continue to live in poverty at three times the rate of Whites; 60 percent of Mexicans and their U.S.-born children continue to live in near poverty (less than $200 \%$ of the poverty threshold) after the second generation (López \& Velasco, 2011). When children live in poverty or near poverty, they are less likely to receive medical services, because of a lack of insurance, for ear infections, vision problems, influenza, and other illnesses. These children may then miss out on schooling, adding to the challenges teachers face in teaching literacy and other content areas. The distribution of sadness expands to education in other ways as well. In California, Arizona, and elsewhere, new and existing elementary and secondary teachers are woefully underprepared for the kinds of language and content challenges children of immigrants face in school (Gándara \& Contreras, 2010). In the past decade, many of the children designated as English learners are being relabeled as longterm English learners, a euphemism for the failure of schools to adequately address their needs. In states where large numbers of children of immigrants enter school as emergent bilinguals, professional development initiatives rarely support preparing secondary teachers in learning how to teach content areas to English learners (Gándara, Maxwell-Jolly, \& Driscoll, 2005; Reeves, 2006).

\section{The Distribution of Disdain}

In the past decade there has been what I refer to as a "distribution of disdain" toward Mexican-origin families and children. Undocumented Mexican immigrants and their children have been especially targeted, resulting in new laws, policies, and practices ranging from profiling, denial of basic health services, English-only instruction that segregates newcomer English learners from mainstream school populations, and minimal focus on learning to teach English learners in mainstream classrooms. The message of disdain and at times outward hatred toward Mexicans and their children, regardless of their legal status, their contribution to the construction of the United States, and the fact that family connections have been built for multiple generations, is that they are not welcomed across the United States. This disdain, motivated by fear of a "Mexican takeover," is distributed throughout society in health, welfare, and schooling. Increasingly, more and more anti-immigrant voices are calling for the mass incarceration and deportation of children and adults of Mexican origin. 
To provide an example of the disdain toward Mexican immigrants, I focus on Arizona, the state I am most familiar with. In 2007, "State Legislator Russell Pierce (R-Mesa) called for a return of the 1950s racist, mass deportation program, known as "Operation Wetback" to round up and deport immigrantsmen, women, and children-to Mexico" (Faltis, 2007, p. 8). Ten years earlier, the Maricopa County Sheriff's department, under the direction of Sheriff Joe Arpaio, rounded up people thought to be Mexicans, documented and undocumented, in Chandler, a small city outside of Phoenix, breaking up families and sending people to Mexico without checking their legal status (see Romero, 2006). According to Romero, the sheriff's department relied on a little known legality that permits profiling for "browness," as a reason, along with any other minor technicality, to stop, arrest, and eventually deport undocumented Mexicans. Being brown, equated with potentially being criminal and foreign, along with a broken taillight or suspicious looking activity, enabled the sheriff's department to question the resident status of Mexican immigrant families. In 2008, the Maricopa Sheriff's Department conducted numerous raids throughout metropolitan Phoenix under the guise of looking for "criminal, illegal aliens." In 2009, Sheriff Arpaio was ordered by the Federal Government to stop profiling and rounding up Mexican immigrants (see González, 2009). The practice continued nonetheless, with 800 new deputies unleashed in mid-February, 2010 to arrest people profiled as Mexicans (Fernández, 2010). Several months later, the Arizona legislature passed the Support our Enforcement and Safe Neighborhoods Act, also known notoriously as SB 1070, which at the time was the strictest anti-immigration measure in recent U.S. history ${ }^{1}$. This law essentially enabled state law enforcement officials to profile Mexican-looking people and ask them for their residency papers. Since the Arizona anti-immigrant law, five states - Alabama, Georgia, Indiana, South Carolina, and Utah - have passed SB1070 copycat antiimmigrant measures (ACLU, 2012) ${ }^{2}$, showing that the distribution of disdain is spreading.

\section{My Stance toward Social Justice for Mexican Immigrants in the United States}

In the spirit of full disclosure, societal and cultural expressions of disdain toward Mexican immigrants, juxtaposed with the distribution of sadness, have fueled much of my own work over the past 25 years. I have worked to counter anti-immigrant discourse toward Mexican immigrant families in my written, visual, and multimedia texts and my teaching. I worked and lived in Phoenix, Arizona, from 1991 to 2008, where I taught courses at Arizona State University on bilingualism and immigrant communities and worked with teachers in schools serving large populations of children of Mexican immigrants. I share VelezIbañez's sorrow about the conditions of poverty, poor schooling, and health issues faced by children of Mexican immigrants. In my interactions with students, community members, and broader audiences who read my text-based work, I have sought to present critical arguments, empirical evidence, and culturally and linguistically relevant practices that build on the contribution Mexican immigrants 
and their children bring to the United States and to the Southwest in particular. I have drawn from counter-hegemonic work conducted in schools and communities where children of Mexican immigrants attend school and live (Aparicio, 2000; Bartolomé, 2008; Gándara \& Contreras, 2010; Trueba, 1989; Valdés, 2001; Valenzuela, 1999), to share with readers and students a pedagogy of struggle and hope for improving educational practices and conditions for Mexican immigrant students and the children of Mexican immigrants.

My affinity for art encompasses the aesthetic of visceral realism which, drawing on Bolaño (1998), means realistically rendered art (poetry, photography, painting, and drama) that portrays people, things, and situations from lived experiences, intensified by the artist's visceral emotions towards social injustice and inequity in school and society. My intent in creating and sharing this art is to provoke readers and viewers to think and have conversations about immigration, the people who immigrate, and the way Mexican immigrant adults and their children have been treated in society and schools. My own lived experiences within the distribution of sadness and disdain toward Mexican immigrants has triggered my visceral emotions to go beyond the textual scholarship and into the world of art and political scholarship as a way to promote understandings of others.

\section{Art and Political Scholarship}

In 2005, I began exploring how art, specifically oil paintings depicting Mexican immigrant images through my view of visceral realism, might add to critical educational and policy conversations tied to issues that many, including myself, have intended to convey in the text-based literature on Latinos and education. Maxine Green (1995) argues that the arts have the unique power to expand the imagination toward the unimagined and the uncertain. I chose oil paintings to expand my imagination about Mexican immigrants beyond the writings I have created and read for several reasons. In oil paintings, colors and tone can be used to evoke symbolic as well as denotative meaning. With oil paintings, the issues of color, tone, perspective, and symbolism enable the artist to attend to multiple topics, political stances, and emotions, without necessarily organizing them logically or sequentially, as is the case within textual representations. For example, I use hot tones (reds, yellows, and oranges) for certain kinds of emotive content, along with dark and light tones to represent realistically the content I am interested in portraying. As a visceral realist artist interested in anti-immigrant discourse, the question that I posed across all of the paintings I created about Mexican immigration issues and topics was, "How can I create art to provoke emotive and denotative meanings interconnected to textual representation, which simultaneously create openings for the unfolding of visceral sensations and critical meaning about the topics of my work?" In my art, I selected and constructed ideations that weave in what I have learned and written about in response to the distribution of sadness associated with the widespread, burgeoning disdain expressed toward Mexican immigrants in the United States. 
I think of art as a form of political scholarship in the sense that the images I create reflect my social construction of the treatment of Mexican immigrants in society and of their children in schools. Art is not a scientifically based approach to understanding social issues and educational problems. Rather, art is an opportunity to express and share meanings through images in ways that reflect certain understandings and ideologies, but do so in ways that are unpredictable with respect to how viewers behold and interpret the meanings they bring to and take from the form and content of the art. The creation of form and content in an artistic piece emerges from the experiences and affinities of the artist, including lived inquiries through social interaction, visual experiences, and textual artifacts. In my case, I wanted to create art forms that included content about issues I held close to my political and ideological narratives concerning social justice issues around the education of children of Mexican immigrants and anti-immigrant discourse writ large.

A process that I found particularly appealing to understand the art I was creating and its relation to text is what Springgay, Irwin, and Kind (2005) refer to as double-imaging. In this process, words and art do not merely illustrate each other, but they weave through one another to create new complex meanings and critical understandings of topics that by themselves have distinct meanings and understandings ${ }^{3}$. Rogoff (2000, as cited in Springgay, Irwin, \& Kind, 2005, p. 899) argues that text and art about the same topics are necessarily interconnected, not because they transfer meaning from one realm to the other, but because they "speak in conversation with, in, and through art and text such that encounters are constitutive rather than descriptive." This double-imaging allows for a living inquiry (Springgay, 2003) into complex questions that cannot be answered by relying on text or art alone. Double-imaging is not a one-to-one correspondence between text and art; it is an imaginative pairing of emotive images with text-based experiences.

\section{Visceral Realism in Art and Text around Mexican Immigrants}

In the following sections, I attempt to show how texts and art converge to engage in a lived inquiry about anti-immigrant discourse referring to Mexican immigrants by interweaving art and text in ways that respond to both the distribution of sadness and the distribution of disdain mentioned above. The series of paintings below (Figures 1-9) represent a body of work on borders and border crossing in ways that provoke emotive, constitutive meanings. I incorporate the borders in the sense of a real barrier used to keep peoples apart, and metaphorically to symbolize that borders contribute to the distribution of sadness and to the disdain that is emblematic of anti-immigrant discourse. All of these paintings were created between 2005 and 2011 as events were unfolding nationally around topics of immigration and schooling, in both text and real life. 


\section{The Rise of the Borders to Keep Mexican Immigrants Out}

I begin with a painting of Mexican immigrants at the border fence where there are crosses marking the deaths of young people who have tried to cross the desert into the United States. The idea that Mexicans, who have been coming into U.S. territories for hundreds of years, now experience a physical border has been written about in sociology and education research literature. What I wanted to create here was a lasting image of what a physical border in the U.S. conveys. My experience across the nation is that most people have never seen a border fence, and I hope viewers will question the place names on the crosses and wonder about the window of opportunity these two young men are peering through.

Figure 1. Border Crossing. C. Faltis, 2005

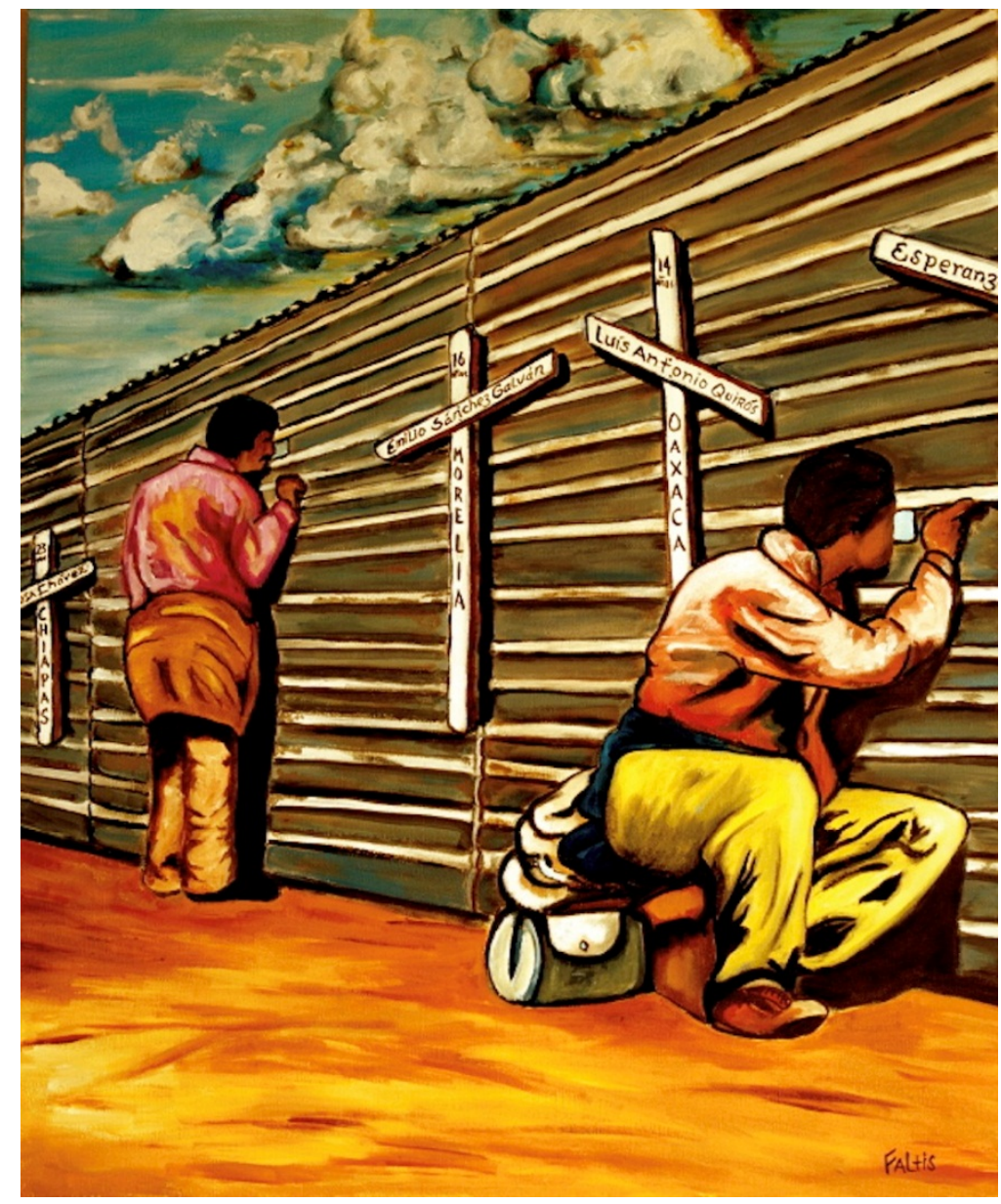

I created this image in part from my lived experiences interacting with and being among Mexican immigrants throughout my youth and adult life in 
California, Arizona, and Mexico. As an educator, I was also keenly aware of the formidable sacrifices Mexican immigrants make in traveling "al norte." One of the meanings I intended this painting to represent is hope for new and continuing opportunities in the United States, seen against the tremendous risks people take in crossing the border. The name on the cross on the right, "Esperanza" is both a woman's name, and the Spanish word for "hope." I also imagined that for many Mexicans, crossing over might be a return to families and communities that are part of these individuals' personal histories (Ettinger, 2009; Hondagneu-Sotelo, 1997). Two of the places marked on the crosses are cities in which I have lived; one as a school child; the other as an adult. These cities also represent places from which many Mexicans move back and forth between Mexico and the United States.

\section{Death from Border Crossing}

In this next painting, I drew on my knowledge of the dangers of crossing the desert for many Mexican families, juxtaposed with the meanings of life and death in Mexican and Mexican indigenous belief systems. I also tied in Aztec-like design to show that pre- and post-Columbian civilizations from what is now Mexico have been traveling northward and back for centuries. For many Mexicans, coming to Arizona, California, and Texas is reuniting with families who have claimed these regions as home since well before either were won through war and hostilities from Mexico. Reflected in the eyes is the scene from the painting above of Mexicans who now are faced with a physical border that was once well traveled, open, and part of their identities. This art connects to the distribution of sadness. The red chiles underneath the skull express the piquancy of the afterlife, potential for exciting times in the new life, and a glimpse of hope amidst despair. In both of these paintings, I aimed to depict what Velez-lbañez (1996) and others (Suárez-Orozco, Suárez-Orozco, \& Todorova, 2009) have written about the dynamics of transnational traveling, coupled with the continuity of life and death across space and time. As of this writing, thousands of Mexicans, including young children and adolescents, have perished in the desert, in large part due to national policies that funneled Mexican immigrants into the treacherous terrains of northern Mexico and Southern Arizona (See Regan, 2010). 
Figure 2. Danger and Hope. C. Faltis, 2007

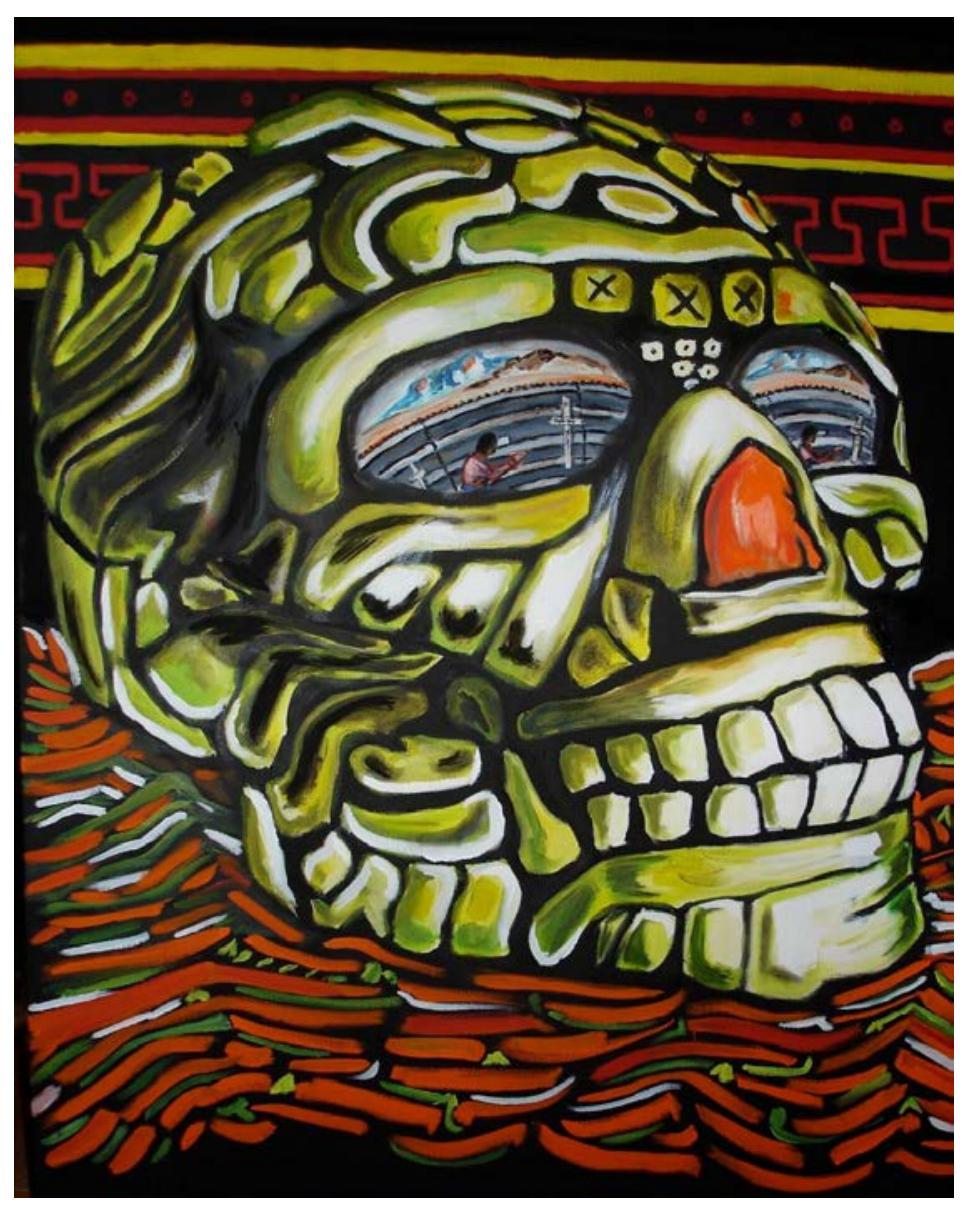

\section{Splitting Families Apart}

One of the greatest tragedies of anti-immigrant policies across the United States (e.g., Arizona, Alabama, Georgia, Mississippi, North Carolina) is the splitting families apart, where fathers, brothers, sisters, cousins, and other close relatives are literally removed from their family units and deported to Mexico. I have witnessed the police and sheriff's department watching Mexican laborers at Home Depot (a large building supply store) and have heard raids on Mexican communities, but it wasn't until I attended a presentation in 2008 by Professor Mary Romero at Arizona State University that I learned about the 1997 Chandler (a suburb of Phoenix, Arizona) round-up where family members were arrested and deported, leaving other families weeping in shock (see Romero, 2006). This round-up was deliberately kept out of the newspapers and local media. Professor Romero showed several photographs of adults and children in fear being rounded up and arrested by county police. Those horrible images and Romero's paper inspired me to create the two paintings below. 
In the border painting (Figure 3), I used dark tones to contrast the border patrol and the light emanating from the Virgen de Guadalupe. I have the Virgen wearing a bandana in ideological solidarity with the Zapatista Army of National Liberation (EZLN), who in the 1990s led an armed struggle for the recognition of human rights, dignity, and political voice (Harvey, 1998). In this case, I intended for the bandana on the Virgen to also signal her indignation at the disdain for Mexican immigrants attempting to cross the border. While many have taken umbrage at the treatment of Mexican immigrants by the border patrol and local sheriffs' departments in text (Hurricane, 2009), I was able to imagine the outrage by evoking a Mexican symbol of protection that is deeply imbedded in Mexican ethos. In this manner, I wove in visceral realism with realities faced by undocumented Mexican immigrants: arrest and deportation.

Figure 3. Crossing Beliefs. C. Faltis, 2006

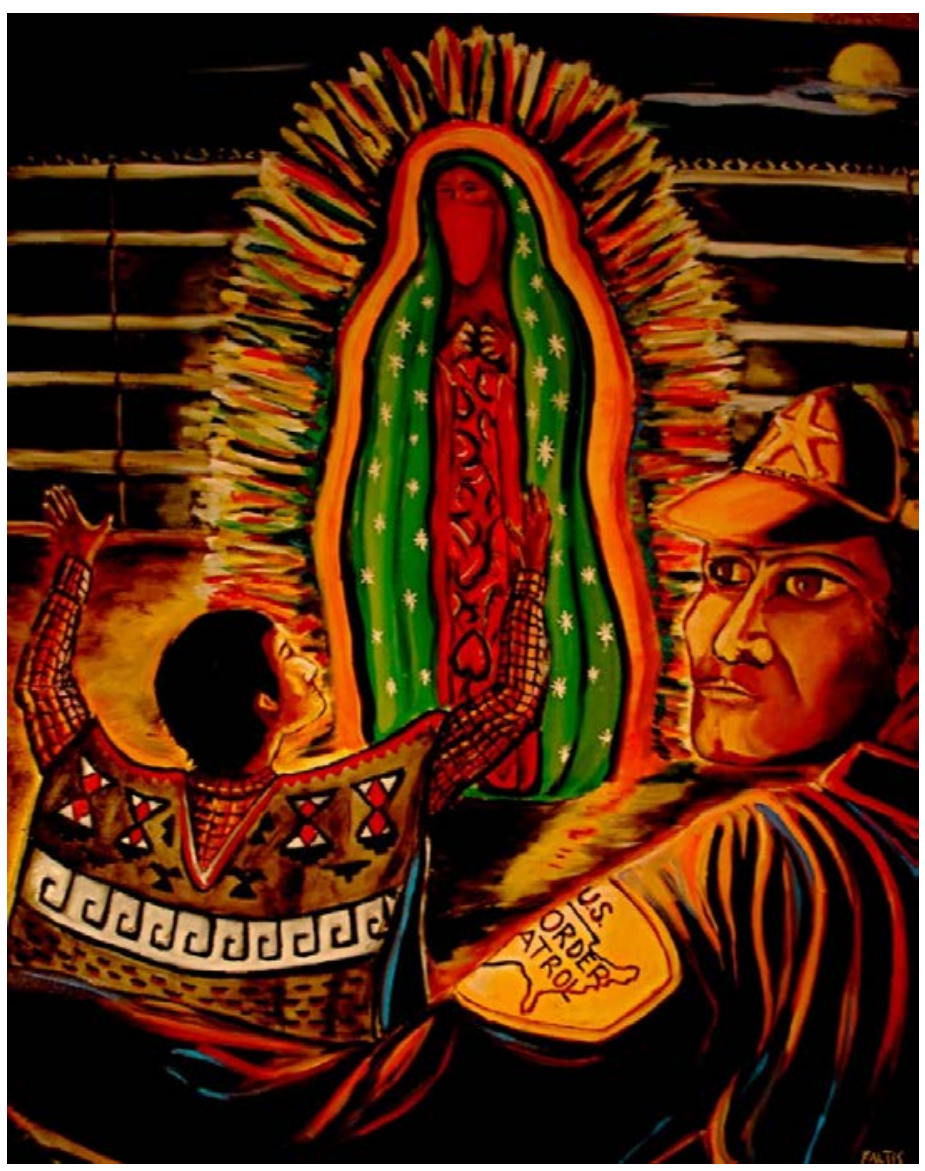

In the second painting (Figure 4), I used bold colors (oranges, reds, and yellows) and a surreal landscape. The man in the foreground is wearing a Dallas Cowboys cap, while the teenage boy has on a Chivas cap. As the two men look back at their families and homes, the girl looks on with a forlorn face, imaging what it must feel like to be torn from one's family. Both the Cowboys and the Chivas represent hugely popular sport teams in their respective countries, the 
United States and Mexico; both teams represent transnational allegiances. The border fence in this painting is much lower than I envision it in other paintings, mainly because I imagined that the families would be reunited eventually, regardless of the border fence. Mexicans who are deported often return again and again to reunite with family members, to keep their children in school, and to resume their work (Portes, 2009; Suárez-Orozco \& Suárez-Orozco, 2007).

Figure 4. Families Apart. C. Faltis 2009.

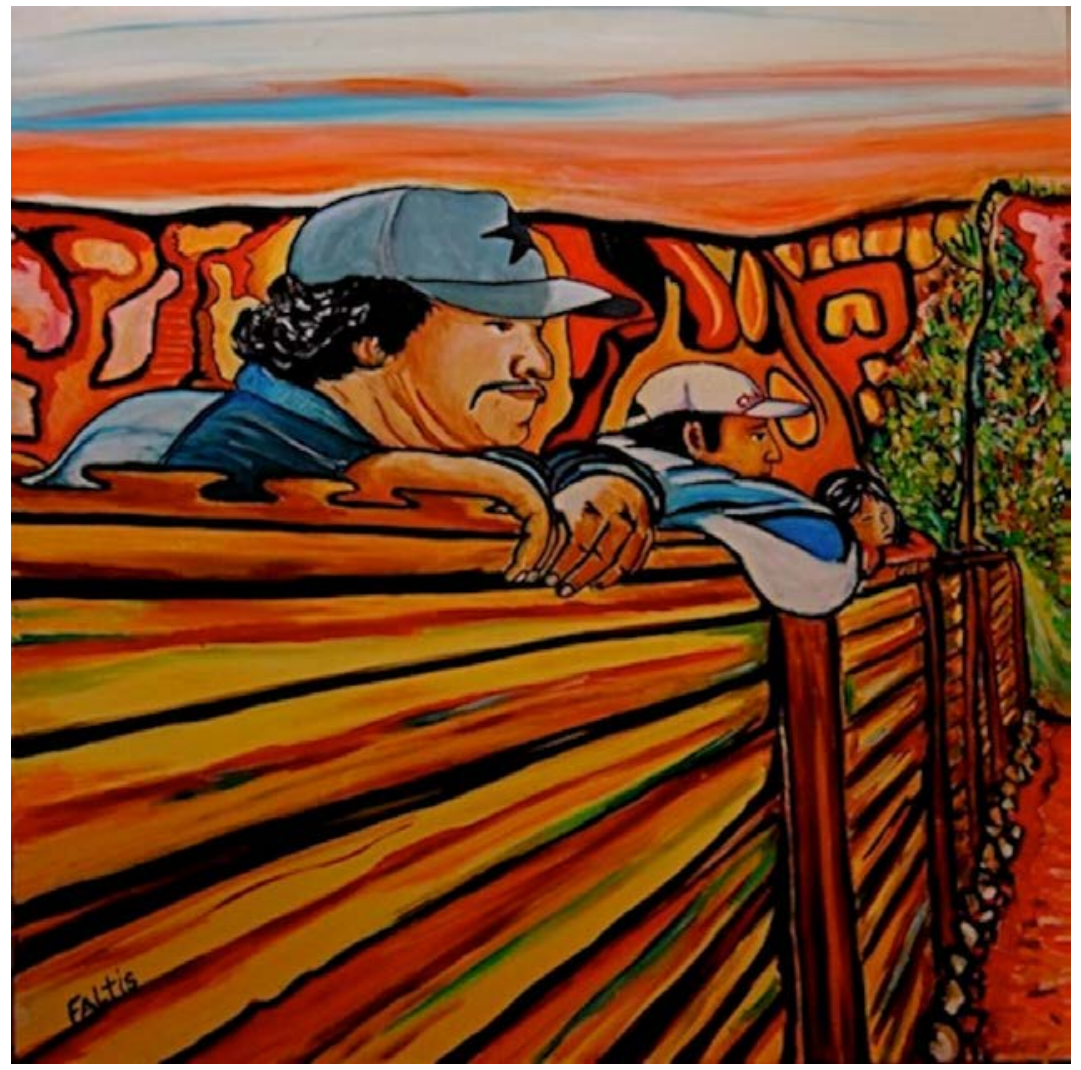

\section{Schooling and Mexican Immigrants}

In 1994, California passed Proposition 187, which sought to prohibit state and local governments from providing non-emergency health care and social services to undocumented immigrants. This proposition also had a provision to deny K-12 public education to undocumented immigrants (Valencia, 2008), a provision that was eventually struck down because it violated the Supreme Court ruling in Plyler v. Doe (1982), based on a case in Texas, which found that all children have the right to attend public education regardless of the status of their parents (See López \& López, 2010, for an extensive analysis of the case). Although the attempt to overturn Plyer $v$. Doe was foiled in California, other states have continued to propose statues in direct contravention of Plyler as a way to have schools verify the immigration status of students' parents before 
their children can enroll in public elementary and secondary schools (Valencia, 2008 , p. 249). So far, every attempt to add such a provision has been found unconstitutional and illegal. Nonetheless, efforts in several states to deny educational services to the children of undocumented immigrants remain strong (López \& López, 2010). This is part of the disdain toward Mexican immigrant families.

I created the painting in Figure 5 based on visual representations in a pamphlet that was issued by the Mexican government to provide information about legal and health support to Mexicans crossing into the United States. I wanted to bring attention to the U.S. Supreme Court case of Plyler v. Doe to engage viewers in a discussion about the basic rights to public education that people have in the United States (López \& López, 2010). I imagined the Virgen with a bandana and placed the border fence in the background to show that efforts to close off schools to children of Mexican immigrants, many of whom are born in the United States, represent the building of a new border that denies basic rights for education.

Figure 5. Plyler Rights for Immigrants. C. Faltis 2010

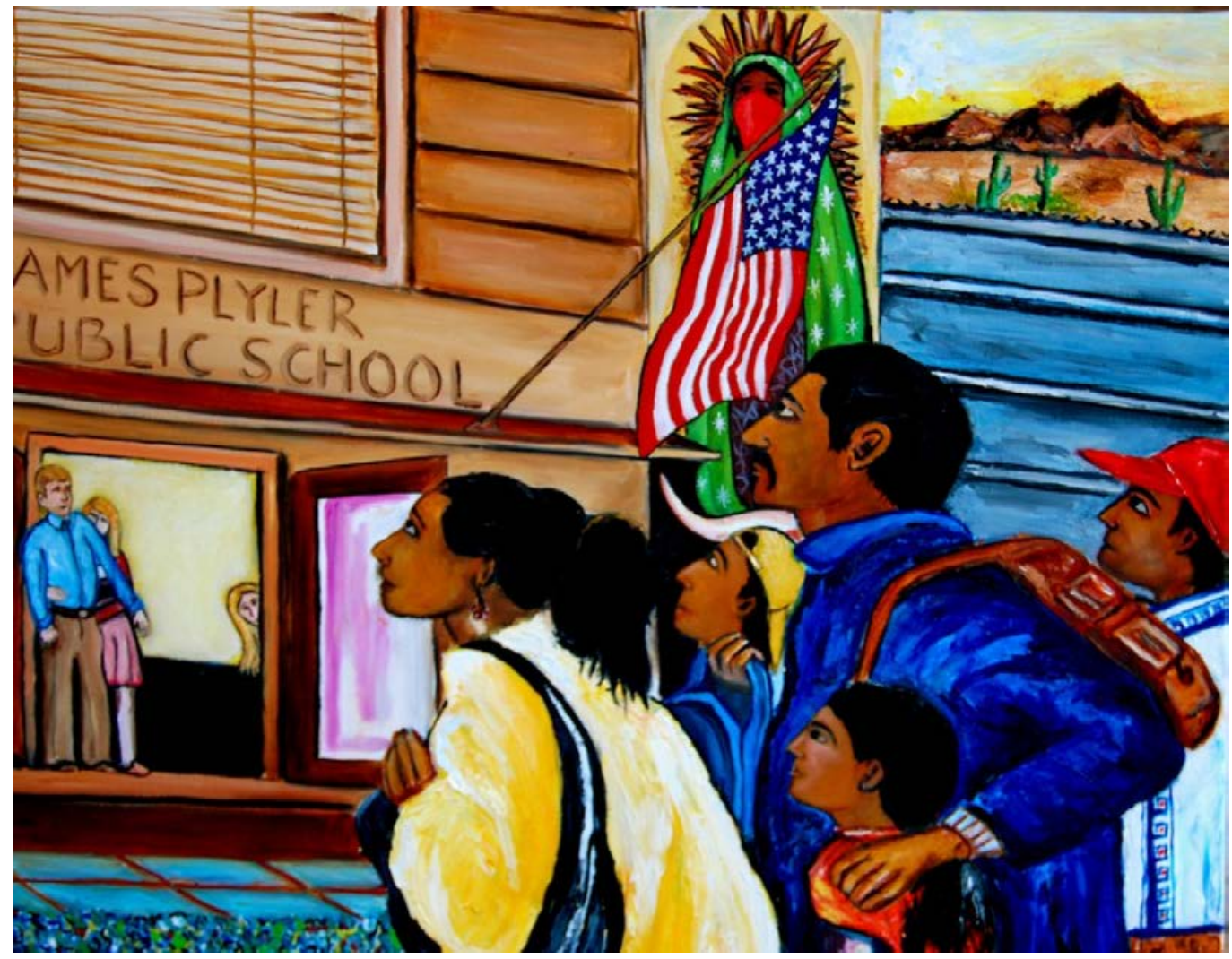

Even though both U.S.-born and Mexico-born children of documented and undocumented immigrants currently have the right to attend public schools across the nation, many of the schools these students attend have inadequate resources (Gándara \& Rumberger, 2007). Teachers who work in these schools 
are often underprepared to meet the language and learning needs of children of immigrants and English learners (Gándara \& Contreras, 2010; Súarez-Orozco, Súarez-Orosco, \& Todorova, 2009). And some teachers do not want to have English learners in their classrooms (Reeves, 2006). Much of my text-based work (Faltis, 2001; 2006) has been a long-term effort to help teachers provide classroom environments in which all children, regardless of their language, social status, and ethnicity, can participate in all learning experiences. I created the painting below (Figure 6) in an attempt to capture the complexities for teachers of having English learners in their classrooms without knowing exactly how or not wanting to integrate language and content instruction for optimal second language instruction. This double-image incorporates the text of my writing through an artistic rendering of visceral realism about many U.S. classrooms, with an invitation to engage in discussions about what it means to have Mexican immigrant children in schools that are expected to teach all children.

Figure 6. No More Borders vs. No More Immigrants. C. Faltis 2008

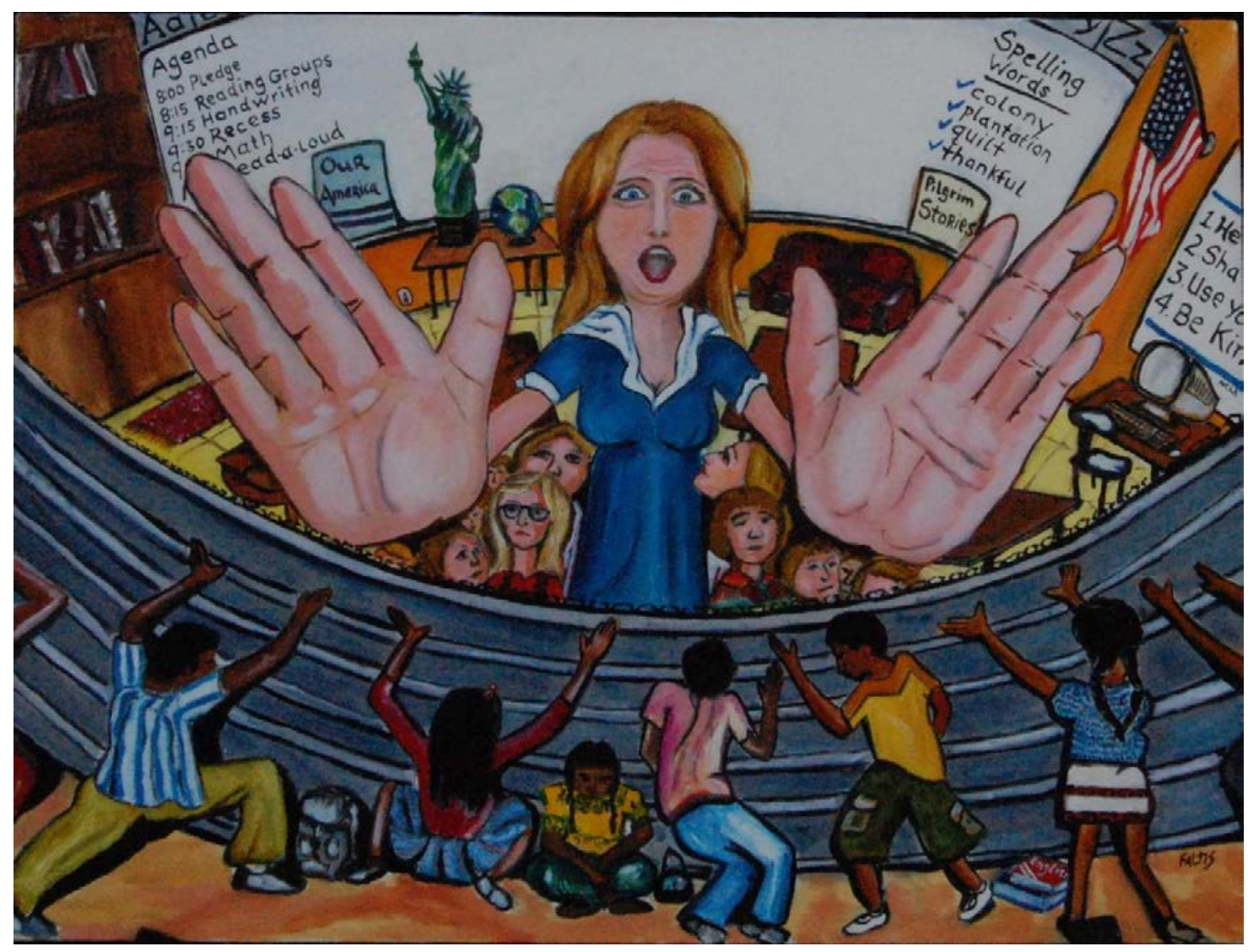

Many states with large Mexican immigrant populations have implemented restrictive language policies requiring teachers to teach English learners in English only. English-only instruction is an educational remedy that is largely 
unsupported by educational theory and viewed as unsound by the vast majority of researchers and experts in the field of language minority education (Haas \& Gort, 2009). For example, the written text-based research on quality instruction for English learners appears unanimous on these two findings:

1. Students learn best in a language they understand and can use to learn new content. "...students learn when the teacher builds on frameworks of knowledge - or "schemata" that students already possess. That is, teaching is most effective when new learning is tied to what students already know. Thus, by teaching students concepts in a language they understand, one can advance the learning in other subject areas while also teaching the students English" (Gándara \& Contreras, 2010, p. 134).

2. Literacy practices are developed most efficiently in the language students already know and use to make sense of their worlds. "Once you can read, you can read. Being literate in one language makes it easier to develop reading ability in additional languages" (Crawford \& Krashen, 2007, p. 20).

Despite these widely accepted findings, the mandate that "all instruction shall be in English," adds a new border to schooling experiences of English learners. In the painting below (Figure 7), I painted a young student trying to make sense of a book written, and most likely discussed, in an unfamiliar language. The book is portrayed as a painful border that not only limits access to learning, but also one that disregards the axiom that children learn to read in the language they understand and use in their local practices. It is intentional that the book the boy is holding and trying to read was authored by Ron Unz. Some readers may not know that Ron Unz was the millionaire engineer from Silicon Valley who spearheaded the political drive in California, English for the Children, to eliminate all forms of bilingual education except dual language immersion and replace it with English only instruction. The Unz initiative was also successful in eliminating bilingual education in Arizona and Massachusetts. This painting does double-duty in the sense that it combines having students learn to read in a language that does not make sense to them with the borders that English-only language policy creates for students by not having full access to knowledge and experiences acquired in their home language. Accordingly, English for the Children is portrayed as a border rather than a gateway to successful schooling. 
Figure 7. Reading Borders. C. Faltis, 2008

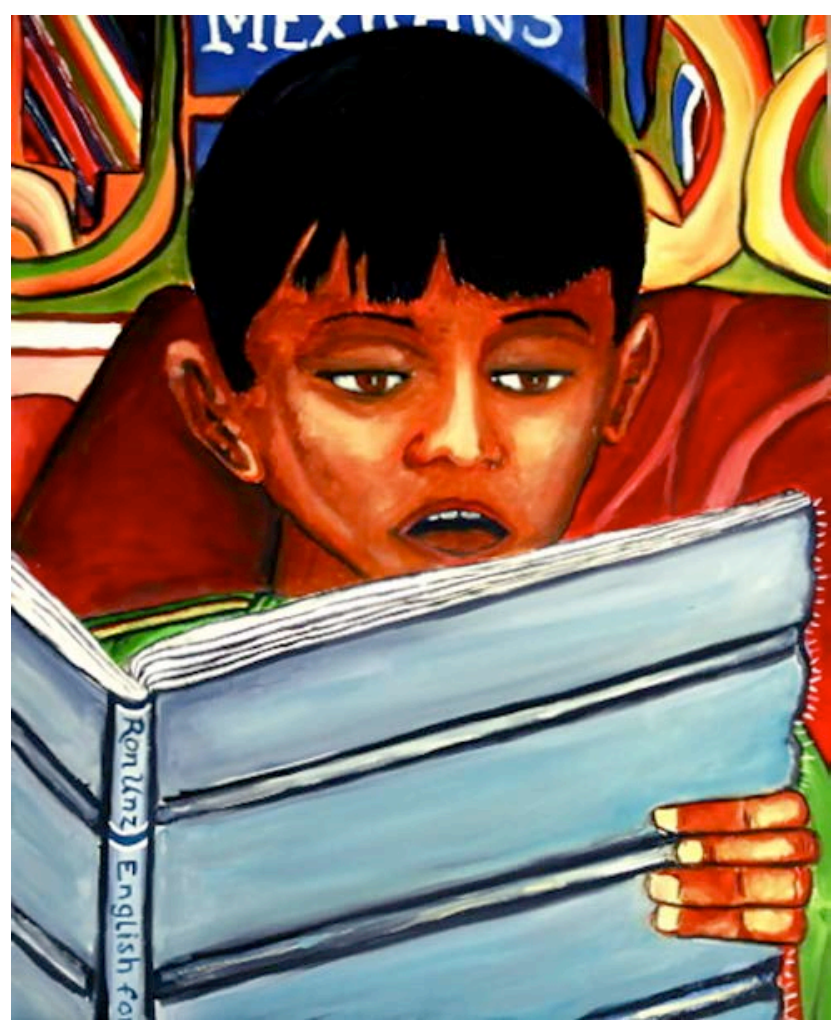

One potentially harmful effect of restrictive language policies is the separation and tracking of Mexican immigrant students in elementary and secondary school levels around English language proficiency levels. For example, in Arizona, according to Arizona Revised Statute 15-756/01, English learners below advanced proficiency in English are required to be placed in classes with students who are at their same level of English proficiency for four hours per day for a minimum of one year. This policy not only isolates English learners from students of other, higher levels of English proficiency, but also denies them access to subject matter content they will need to progress in school. According to Haas and Gort (2009), this practice may be illegal because it does not follow what experts know is needed for quality instruction for English learners, as required by Castañeda v. Pickard (1981). Keeping lower level English learners segregated from English speakers is part of a national trend, leading several scholars to declare that Latino immigrant students who are English learners are now the most segregated of all minority students in U.S. schools (Frankenberg, Lee, \& Orfield, 2003; Gifford \& Valdés, 2006).

In the next painting (Figure 8), which I titled Me llamo Jorge, I attempted to capture the isolation many English learners, particularly at the secondary level, face in school ${ }^{4}$. In this painting, you can see a letter taped to the border wall surrounding Jorge, which says: Me llamo Jorge. Hablo español pero todo está en inglés y por eso no puedo participar y no entiendo lo que trato de leer. [My name is Jorge. I speak Spanish but everything is in English so I can't participate and I 
don't understand what I try to read.] The goal of this painting is to keep the discussion open about the effects of segregation policies and practices, which I suspect contribute significantly to large numbers of Mexican immigrant students and children of Mexican immigrants being designated as long-term English learners and ultimately leaving school before graduation.

Figure 8. Me llamo Jorge. C. Faltis, 2009

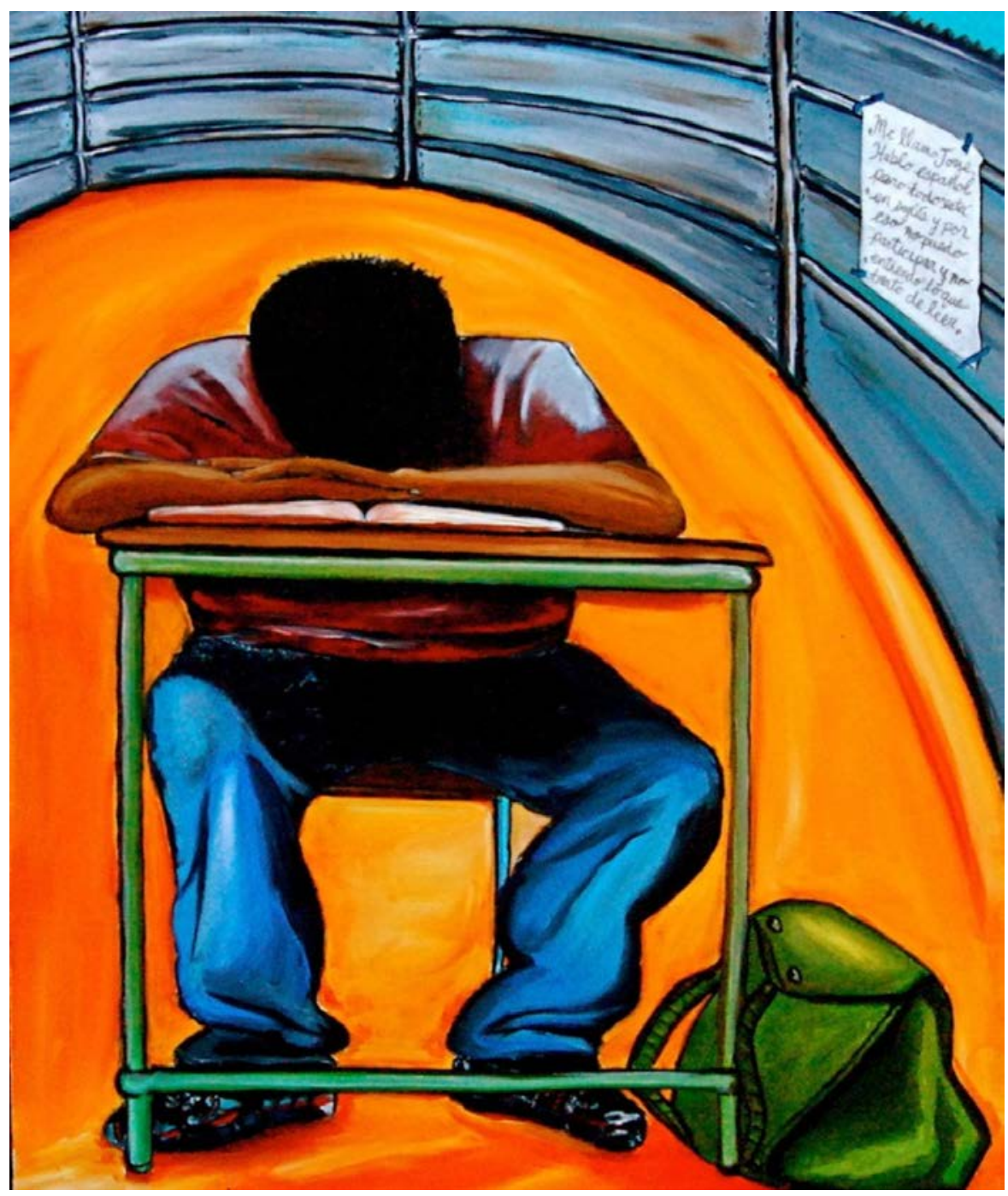

\section{Raising Silent Voices}

Critical ethnographer and educator Henry Trueba (2002, p. 25) argues that "universities and colleges, absorbed in their petty politics, are trying to figure out how to prepare future generations of teachers who will have to work with new school populations representing many languages and cultures...." In the meantime, we can hope to raise the silent voices (Trueba, 1989) of the immigrant children and families who for too long have been suppressed by dominant forces 
aiming to deny them access to quality schooling, where language is part of one's identity and cultural pride rather than a problem, and "the capacity to imagine worlds we, the senior generations, cannot even imagine" (Trueba, 2002, p. 25.). The final painting (Figure 9) is a tribute to Henry Trueba, whose work and dedication to immigrant children spanned nearly 40 years, informing my work and that of countless others. I have painted Trueba's book as an image within a double-image: What I learned from Trueba's work represents for the woman in the painting a way to express the realities of social injustice experienced by Mexican immigrants.

Figure 9. Raising Silent Voices. C. Faltis, 2010

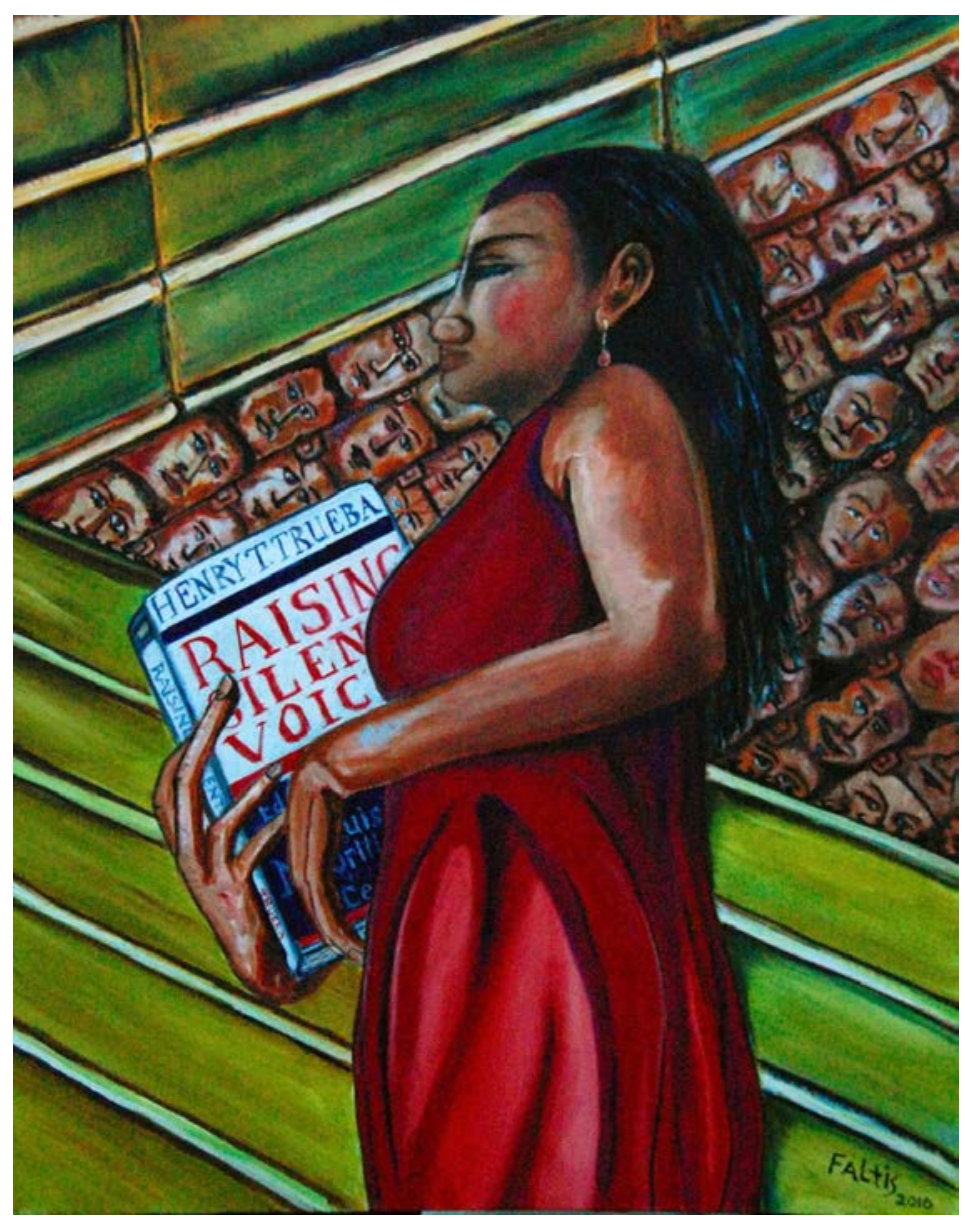

It is certain that children of Mexican immigrants will soon become, and in many areas of the country already have become, a majority population in the United States. "Their well-being, particularly their health and education, and their own investments in their futures, constitute a shared responsibility between their families and the public sector" (Takanishi, 2010, p. 2). Efforts to improve health and education for immigrant children of Mexican origin need to be a top priority in the coming years; the nation depends on it. The art that I have included in this paper is part of my contribution as a scholar, educator, and social activist to 
social justice and equity for Mexican immigrants. I recognize that none of my efforts to create through art the visceral realism of my experiences would have been possible for me without the personal commitment to text-based scholarship that has been part of my social and cultural reality over the past half of a century. Art and text must continue to challenge the dominant anti-immigrant script, ever encouraging viewers and readers to tear down borders that separate people and communities.

\section{Notes}

1. SB 1070 was signed by Governor Jan Brewer on April 23, 2010. Civil rights lawyers challenged the law, and one day before the law was scheduled to take effect a federal judge issued an injunction to halt the provision that enabled state law enforcement officers to stop, detain, or arrest people who they suspected to be illegal immigrants.

2. State Legislator Russell Pearce was recalled in November, 2011, with voters rejecting his association with White supremacist groups and his extreme views on immigration. In December, 2011, an investigation was initiated into multiple forms of discrimination Sheriff Joe Arpaio is alleged to have used against Mexican-origin inmates at the Maricopa County Jailhouse.

3. Double-imaging differs from intertextuality, which is the shaping of a text's meaning by other texts, and the interconnections among texts. In doubleimaging the interconnections are between and through images in art and meanings derived from text.

4. The title of this painting did not come from the children's book, My name is Jorge: On both sides of the river (Medina, 1999). I named it independently of this book.

\section{References}

Aparicio, F. (2000). Of Spanish dispossessed. In R. Dueñas González \& I. Melis (Eds.),Language ideologies: Critical perspectives on the official English only movement (pp. 258-275). Mahwah, NJ: Lawrence Erlbaum.

Bartolomé, L. (Ed.). (2008). Ideologies in education: Unmasking the trap of teacher neutrality. New York, NY: Peter Lang.

Bolaño, R. (1998). Los detectives salvajes. Barcelona, Spain: Editorial Anagrama.

Castañeda v. Pickard, 648 F. 2d 989 (1981).

Crawford, J. (1994). Bilingual education: History, politics, theory and practice. San Francisco, CA: Bilingual Educational Services.

Crawford, J., \& Krashen, S. (2007). English language learners in American classrooms: 101 questions, 101 answers. New York, NY: Scholastic. 
Ettinger, P. (2009). Imaginary lines: Border enforcement and the origins of undocumented immigration, 1882-1930. Austin, TX: University of Texas Press.

Faltis, C. (2007). Immigrant students in U.S. schools: Building a pro-immigrant, Englishplus education counterscript. Journal of Global Initiates: Policy, Pedagogy \& Perspectives, 2(1), 5-25.

Faltis, C. (2006). Teaching English learners in elementary school communities: A joinfostering approach. New York, NY: Merrill.

Faltis, C. (2001). Joinfostering: Teaching and learning in multilingual classrooms. New York, NY: Prentice-Hall.

Fernández, V. (2010). Arizona sheriff Arpaio to unleash 800 deputies on undocumented. New America Media, February, 15. Retrieved from http://news.newamericamedia.org/news/view_article.html?article_id= 02e68788da8ae19e80db0e37da64848e\&from=rss

Frankenberg, E., Lee, C., \& Orfield, G. (2003). A multiracial society with segregated schools: Are we losing the dream? Cambridge, MA: The Civil Rights Project.

Gándara, P., \& Contreras, P. (2010). The Latino education crisis: The consequences of failed social policies. Cambridge, MA: Harvard University Press.

Gándara, P., \& Rumberger, R. (2007). Defining an adequate education for English learners. Unpublished revised paper. Retrieved from http://www.stanford.edu/ hakuta/Courses/Ed205X\%20Website/Resources /Gandara\%20\%20Rumburger\%20EL\%20Resources.pdf

Gándara, P., Maxwell-Jolly, J., \& Driscoll, A. (2005). Listening to teachers of English language learners: A survey of California teachers' challenges, experiences, and professional development needs. Los Angeles, CA: University of California Regents.

Gifford, B., \& Valdés, G. (2006). The linguistic isolation of Hispanic students in California's public schools: The challenge of reintegration. Yearbook of the National Society for the Study of Education, 105(2), 125-154.

González, D. (2009). Experts call ICE program used by Arpaio a failure. Arizona Republic, Retrieved from http://www.azcentral.com/community/ahwatukee/ articles/2009/02/26/20090226icereport.html

Green, M. (1995). Releasing the imagination: Essay on education, the arts, and social change. San Francisco, CA: Jossey-Bass.

Haas, E., \& Gort, M. (2009). Demanding more: Legal standards and best practices for English language learners. Bilingual Research Journal, 32, 115-135.

Harvey, N. (1998). The Chiapas rebellion: The struggle for land and democracy. Durham, NC: Duke University Press. 
Hondagneu-Sotelo, P. (1997). The history of Mexican undocumented settlement in the United States. In M. Romero, P. Hondagnew-Sotelo, \& V. Ortiz (Eds.), Challenging fronteras: Structuring Latina and Latino lives in the U.S. (pp. 115-134). New York, NY: Routledge.

Horne v. Flores, Nos. 08-289 and 08-294, 557 U.S., 129 S.Ct. 2579 (Cornell Law Website; Decision Announced June 25, 2009).

Hurricane: The Human Right Immigrant Community Action Network (2009). Guilty by immigration status: A report of U.S. violations of the right immigrant families, workers and communities in 2008. Oakland, CA: National Network for Immigrant and Refugee Rights.

Lau v. Nichols, 414 U.S. 563 (1974).

López, M. P., \& López, G. (2010). Persistent inequality: Contemporary realities in the education of undocumented Latino/a students. New York, NY: Routledge.

López, M. H., \& Velasco, G. (2011). Childhood poverty among Hispanics sets new record, leads nation. Washington, DC: Pew Hispanic Center. Retrieved from http://www.pewhispanic.org/2011/09/28/ childhoodpoverty-among-hispanics-sets-record-leads-nation

Portes, A. (2009). Migration and development: Reconciling opposite views. Ethnic and Racial Studies, 32(1), 5-22.

Plyler v. Doe (1982). 457, U.S. 202.

Reeves, J. (2006). Secondary teacher attitudes toward including Englishlanguage learners in mainstream classrooms. Journal of Educational Research, 99(3), 131-142.

Regan, M. (2010). The death of Josseline: Immigration stories from the Arizona borderlands. Boston: Beacon Press.

Rogoff, I. (2000). Terra infirma: Geography's visual culture. New York, NY: Routledge.

Romero, M. (2006). Racial profiling and immigration law enforcement: Rounding up of usual suspects in the Latino community. Critical Sociology, 32(2-3), 447-473.

Rosales, A. (1999). Pobre raza: Violence, justice, and mobilization among Mexico lindo immigrants, 1900-1936. Austin, TX: University of Texas Press.

Springgay, S. (2003). Communities seeing themselves seeing: Visual art as educational research. Paper presented at the annual meeting of the American Education Research Association, Chicago. Retrieved from http://wwwlcoe.iup.edu/kjkmoran

Springgay, S., Irwin, R., \& Kind, S. (2005) A/r/tography as living inquiry through art and text. Qualitative Inquiry, 11(6), 897-912. 
Suárez-Orozco, M., \& Suárez-Orozco, C. (2007). Moving stories: Immigrant youth adapt to change. Du Bois Review: Social Science and Research on Race, 4, 251-259.

Suárez-Orozco, C., Suárez-Orozco, M., \& Todorova, I. (2009). Learning in a new land: Immigrant students in American society. Cambridge, MA: Harvard University Press.

Takanishi, R. (2010). Introduction. In E. Gregorenko \& R. Takanishi (Eds.), Immigration, diversity, and education (pp.1-6). New York, NY: Taylor \& Francis.

Trueba, H. T. (1989). Raising silent voices: Educating linguistic minorities for the $21^{\text {st }}$ century. New York, NY: Newbury House.

Trueba, H. T. (2002). Multiple, ethnic, racial, and cultural identities in action: From marginality to a new cultural capital in modern society. Journal of Latinos and Education 1(1), 7-28.

Valdés, G. (2001). Learning and not learning English. New York, NY: Teachers College Press.

Valencia, R. (2008). Chicano students and the courts: The Mexican American legal struggle for educational equality. New York, NY: New York University Press.

Valenzuela, A. (1999). Subtractive schooling: U.S.-Mexican youth and the politics of caring. Albany, NY: State University of New York Press.

Vélez-Ibañez, C. (1996). Border visions: Mexican cultures in the Southwest. Tucson, AZ: University of Arizona Press.

Vélez-Ibañez, C. (2004). Regions of refuge in the United States: Issues, problems, and concerns for the future of the Mexican-origin populations in the United States. Human Organization, 63(1),1-20. 